\title{
Differences between quality of life and occupational coping of tenured and outsourced nurses
}

\author{
Diferenças entre qualidade de vida e coping ocupacional de enfermeiros concursados e terceirizados \\ Diferencias entre calidad de vida y Coping Ocupacional de Enfermeros concursados y subcontratados
}

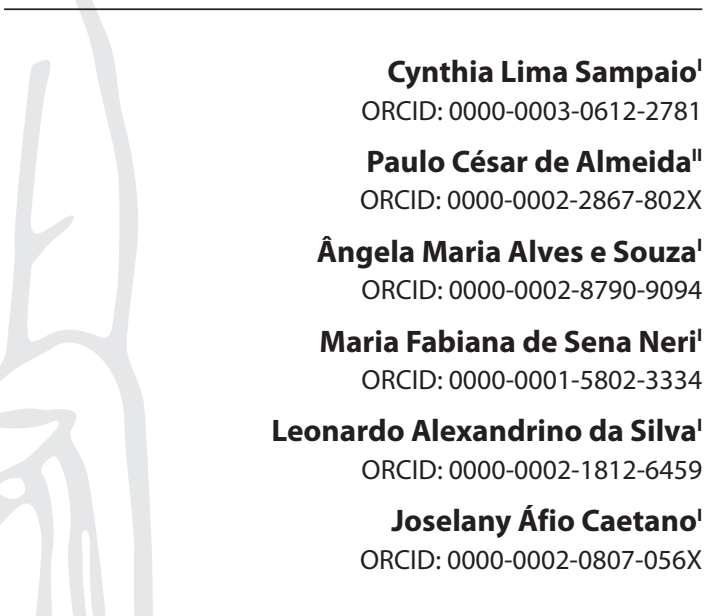

'Universidade Federal do Ceará. Fortaleza, Ceará, Brazil. "Universidade Estadual do Ceará. Fortaleza, Ceará, Brazil.

How to cite this article:

Sampaio LM, Almeida PC, Souza AMA, Neri MFS

Silva LA, Caetano JA. Differences between quality of life and occupational coping of tenured and outsourced nurses. Rev Bras Enferm. 2020;73(Suppl 1):e20190462. doi: http://dx.doi.org/10.1590/0034-7167-2019-0462

Corresponding author: Joselany Áfio Caetano

E-mail: joselany@ufc.br

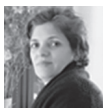

EDITOR IN CHIEF: Antonio José de Almeida Filho ASSOCIATE EDITOR: Hugo Fernandes

Submission: 06-13-2019 Approval: 01-23-2020

\begin{abstract}
Objectives: To compare the relation of quality of life to occupational coping and verify the association of these indicators with sociodemographic variables of tenured and outsourced nurses. Methods: Cross-sectional study, carried out from June to November 2014, with 145 outsourced nurses and 45 tenured nurses. We applied an identification instrument (WHOQOLbref) and Occupational Coping Scale. Student's t-tests and Pearson's correlation coefficient were used. Results: Tenured nurses had better quality of life $(p=0.011)$ and a mean in the Avoidance factor with a strong correlation $(p=0.001)$. Female public servants $(p=0.006 ; p<0.0001)$, between 40 and 66 years old $(p=0.005 ; p=0.031)$, specialists $(p=0.028 ; p=0.005)$, with a family income from 2.5 to 6.8 minimum wages $(p=0.021 ; p=0.006)$ and working in the morning or afternoon $(p=0.043 ; p=0.020)$ and morning and afternoon $(p=0.038 ; p=0.007)$ showed a difference in quality of life and in Avoidance factor, respectively. Conclusion: Tenured nurses demonstrated better quality of life, and some variables trigger differences in the groups, demonstrating the need to promote occupational health.
\end{abstract}

Descriptors: Quality of Life; Adaptation, Psychological; Occupational Health; Outsourced Services; Nursing.

\section{RESUMO}

Objetivo: Comparar a qualidade de vida e o coping ocupacional e verificar a associação desses indicadores com variáveis sociodemográficas de enfermeiros concursados e terceirizados. Métodos: Estudo transversal, realizado de junho a novembro de 2014, com 145 enfermeiros terceirizados e 45 concursados. Aplicou-se instrumento de identificação (WHOQOL-bref) e Escala de Coping Ocupacional. Utilizou-se os testes t de Student e coeficiente de correlação de Pearson. Resultados: Enfermeiros concursados apresentaram melhor qualidade de vida $(p=0,011)$ e média no fator Esquiva, com forte correlação $(p=0,001)$. Os concursados do sexo feminino $(p=0,006 ; p<0,0001)$, entre 40 e 66 anos $(p=0,005 ; p=0,031)$, especialistas $(p=0,028$; $\mathrm{p}=0,005)$, com renda familiar de 2,5 a 6,8 salários $(\mathrm{p}=0,021 ; \mathrm{p}=0,006)$ e atuantes pela manhã ou tarde $(p=0,043 ; p=0,020)$ e manhã e tarde $(p=0,038 ; p=0,007)$ apresentaram diferença na qualidade de vida e no fator Esquiva, respectivamente. Conclusão: Enfermeiros concursados demonstraram melhor qualidade de vida, e existem variáveis que desencadeiam diferenças nos grupos, havendo necessidade de promoção da saúde ocupacional.

Descritores: Qualidade de Vida; Adaptação Psicológica; Saúde do Trabalhador; Serviços Terceirizados; Enfermagem.

\section{RESUMEN}

Objetivos: Comparar la calidad de vida y el coping ocupacional y verificar la asociación de esos indicadores con variables sociodemográficas de enfermeros concursados y subcontratados. Métodos: Estudio transversal, realizado de junio a noviembre de 2014, con 145 enfermeros subcontratados y 45 concursados. Se ha aplicado instrumento de identificación, (WHOQOL-bref) y Escala de Coping Ocupacional. Se ha utilizado los testes $t$ de Student y coeficiente de correlación de Pearson. Resultados: Enfermeros concursados han presentado mejor calidad de vida $(p=0,011)$ y media en el factor esquiva", con fuerte correlación ( $p=0,001)$. Los concursados del sexo femenino $(p=0,006 ; p<0,0001)$, entre 40 y 66 años $(p=0,005 ; p=0,031)$, especialistas $(p=0,028 ; p=0,005)$, con renta familiar de 2,5 a 6,8 salarios $(p=0,021 ; p=0,006)$ y actuantes por la mañana o tarde $(p=0,043 ; p=0,020)$ y mañana $y$ tarde $(p=0,038 ; p=0,007)$ han presentado diferencia en la calidad de vida $y$ en el factor "esquivas, respectivamente. Conclusión: Enfermeros concursados han demostrado mejor calidad de vida, y hay variables que desencadenan diferencias en los equipos, habiendo necesidad de promoción de la salud ocupacional.

Descriptores: Calidad de Vida; Adaptación Psicológica; Salud Laboral; Servicios Subcontratados; Enfermería. 


\section{INTRODUCTION}

Health work often predisposes nurses to stressful situations, which can cause, for example, burnout, which has a prevalence of $1.2 \%$ to $41 \%{ }^{(1)}$. Also, these professionals are vulnerable to physical risks, emotional exhaustion caused by death and suffering because of others, the tension between co-workers, and long shifts. Exposure to all of these factors can trigger fatigue and emotional exhaustion, which cause mental illness and impair quality of life $\mathrm{e}^{(2-3)}$.

The work environment is a significant influence on people's quality of life since it is related to the individual's perception of their position in life, both in physical aspects and in human relationships ${ }^{(4)}$. In this sense, a relationship it is possible to establish between the quality of life and the perception of occupational coping, which is directly related to work overload, social support, and emotional exhaustion.

Coping is defined as the capacity to deal with difficulties and adapt that allows human beings to react to the behaviors, thoughts, and emotions caused by stressful events. Effective coping is considered necessary in the work environment, and the achievement of its organizational objectives depends on the employees' ability to manage work demands. The literature perceives that the relationship between stress and work is recurrent but relatively little is known about the techniques that can improve the effectiveness of dealing with this condition ${ }^{(5)}$.

Studies on quality of life and coping are mostly limited to people with chronic diseases ${ }^{(6)}$, with a reduced amount of research to compare the means of these indicators in health professionals. There are still gaps in investigations with nurses, especially outsourced workers, and, in most cases, this aspect is considered an exclusion criterion, although such workers are a large part of the world reality.

Thus, the compromise of quality of life in health professionals has been widely discussed. However, the investigation of its relationship with occupational coping can contribute to more individualized interventions, intended for a perspective for improving the workers' health and the management of health care work processes. Accordingly, the identification of the most used ways of coping at work can be a strategy to make nurses' daily lives more productive and less stressful. Therefore, we mention the need to compare the quality of life and occupational coping and sociodemographic variables among nurses with different types of employment, such as those who are tenured and outsourced.

Given the above, the following questions arose: Is there a difference between the quality of life and occupational coping between tenured and outsourced nurses? Is there a correlation between the quality of life and occupational coping between tenured and outsourced nurses? What variables interfere in the quality of life and the occupational coping of these health workers?

The present research will contribute to the reduction of the existing gap in scientific evidence about the quality of life, the occupational coping and the variables that present differences in means between the tenured and outsourced professionals, helping in the elaboration of safe and resolute interventions, which can reduce the complications resulting from these phenomena in nursing.

\section{OBJECTIVE}

To compare the quality of life and occupational coping and verify the association of these indicators with sociodemographic variables of tenured and outsourced nurses.

\section{METHODS}

\section{Ethical aspects}

The Ethics Committee of the Federal University of Ceará approved this study. All participants signed the free and informed consent form.

\section{Study Design, location, and period}

Quantitative, cross-sectional study developed from June to November 2014, in a public general tertiary public hospital, in the state of Ceará, Brazil, which performs highly complex services. This hospital attends patients of different age groups and has 541 beds, divided between elective care, emergency, obstetrics, and adult and neonatal intensive care units ${ }^{(7)}$.

\section{Study participants}

The population corresponded to the 640 nurses at the hospital, 438 of whom were outsourced, hired by a cooperative, and 202 were tenured. The sample was stratified, considering the tenured and outsourced nurses, and determined based on the formula for calculating finite populations. We established to calculate the sample size, the p value of $50 \%$, considering that this value entails the maximum sample size. A significance level of $5 \%(\mathrm{Za}=0,05)$ and an absolute sample error of $6 \%(\mathrm{E}=0.06)$ were considered, providing a sample of size " $n$ " equal to 190 professionals. Respecting the proportionality criterion, the sample was calculated to be 145 tenured nurses and 45 outsourced, reaching the values established in the sample calculation. The inclusion criteria were tenured and outsourced nurses, working for at least one year in the current sector. The exclusion criteria were being on vacation or on leave.

\section{Study Protocol}

Three instruments were used, which were filled out by the interviewees in the presence of a nurse student attending a master's degree in nursing. The identification instrument addressed the following variables: gender, age, employment relationship, academic titles, family income, weekly workload, length of work experience in hospital care, unit, and shift in which the nurse works at the hospital.

We used to assess the quality of life, the World Health Organization Quality of Life Bref (WHOQOL-bref), with 26 structured questions, 24 within domains, and two on the perception of health and quality of life. This instrument has four domains and presents questions formulated for a Likert scale, with five levels. The scales are of intensity, ranging from "nothing" to "extremely"; capacity, ranging from "nothing" to "completely"; frequency, ranging from "never" to "always"; and evaluation, from "very dissatisfied" to "very satisfied."These expressions have scores from 1 to 5 , but for questions 3,4 , and 26 , the scores are reversed. The scale ranges from 
0 to 100 , indicating that the higher the value found, the better the quality of life. We calculated the scores of the domains in a statistical program, and the mean of each domain is performed independently ${ }^{(8)}$. The instrument was chosen because it is widely used, created by the World Health Organization, and validated ${ }^{(9)}$ for use with health professionals, in addition to bringing general aspects about quality of life.

The Occupational Coping Scale (OCS) consists of a questionnaire that contains 29 items and covers the thoughts and actions used to deal with internal or external demands of a certain stressful event in the workplace. Each item offers five answer options: I never do this; I rarely do this; sometimes I do this; I often do this; always do this. There are three classification factors: Control factor, Avoidance factor, and Symptom management factor. The Control factor refers to proactive cognitive actions and reevaluations. The Symptom Management factor consists of strategies popularly accepted and used by individuals to manage stress-related events, such as relaxation or physical activity. The Avoidance factor consists of actions and cognitive reevaluations that suggest evasion. The scores for each OCS classifying factor are performed by the mean of the items that compose them, the factor with the highest mean is prevalent one for each nurse ${ }^{(10)}$. OCS, also translated and validated, was chosen because it is easy to apply, Likert-type, and contains questions strictly related to professional problems, making it possible to carry out future interventions.

The choice of these scales made it possible to investigate the relationship between quality of life and socioeconomic data, as well as their relationship with occupational coping since the null hypothesis was that there is a difference between the quality of life and occupational coping for tenured nurses and outsourced.

\section{Data Analysis}

The Statistical Package for the Social Sciences 20.0, license number 10101131007, was used for procedures of descriptive analysis and inferences. The Kolmogorov-Smirnov test was applied to verify the normality of the data, detecting normality in the studied variables. We used the Student's t-test to compare the Quality of Life means and coping. Pearson's correlation coefficient performed the analysis of the linear correlation between these two variables with the quantitative ones. The significance level established was $5 \%$.

\section{RESULTS}

Of the 190 nurses interviewed, the majority of participants were female (90.0\%), aged between 23 and 29 years old (35.2\%), having 3-4 years of work experience in nursing (26.8\%), 1-4 years of work experience in hospital care $(52.6 \%)$, working in units of non-critical care $(51.6 \%)$, working in the morning and afternoon shifts $(30.0 \%)$, specialists $(60,5 \%)$, with $40-59$ hours of weekly workload (44.2\%) and outsourced (76.3\%).

The tenured nurses had a better quality of life (67.18) than outsourced nurses (62.18) ( $p=0.011)$. Only the domains Physical health (70.08; $p=0.025)$ and Environment $(63.36 ; p=0.001)$ contribute to this difference since the tenured workers presented a better mean when compared to the outsourced ones (64.58;
55.40). In the OCS, only the Avoidance factor showed a statistically significant difference $(p=0.001)$ for the tenured nurses (65.92; $\pm 13.59)$ and the outsourced nurses (58.74 \pm 12.71$)$ (Table 1).

Table 1 - Distribution of the means of the quality of life and its domains and the factors of occupational coping occupational for tenured and outsourced nurses

\begin{tabular}{lccc}
\hline & $\begin{array}{c}\text { Tenured } \\
\text { Mean } \pm \text { SD* }\end{array}$ & $\begin{array}{c}\text { Outsourced } \\
\text { Mean } \pm \text { SD* }\end{array}$ & $\begin{array}{c}\boldsymbol{p} \\
\text { value }^{\S}\end{array}$ \\
\hline $\begin{array}{l}\text { WHOQOL-bref } \\
\text { Quality of life }\end{array}$ & $67.18 \pm 11.00$ & $62.18 \pm 11.47$ & 0.011 \\
$\quad \begin{array}{lll}\text { Physical health Domain } \\
\text { Psychological Domain }\end{array}$ & $70.08 \pm 15.50$ & $64.58 \pm 13.91$ & 0.025 \\
$\quad$ Social Relationships Domain & $70.56 \pm 15.30$ & $66.12 \pm 13.95$ & 0.326 \\
$\quad$ Environment Domain & $63.36 \pm 11.91$ & $66.49 \pm 17.22$ & 0.144 \\
OCS & $55.40 \pm 12.61$ & 0.001 \\
$\quad$ Control Factor & $73.88 \pm 9.64$ & $72.41 \pm 12.19$ & 0.491 \\
$\quad \begin{array}{l}\text { Avoidance Factor } \\
\text { Symptoms management }\end{array}$ & $65.92 \pm 13.59$ & $58.74 \pm 12.71$ & 0.001 \\
$\quad$ Factor & $38.39 \pm 16.35$ & $38.83 \pm 18.02$ & 0.885
\end{tabular}

Note: *Standard deviation, ${ }^{+}$World Health Organization Quality of Life Bref, ${ }^{*}$ Occupational Coping Scale, ${ }^{5}$ Student's t-test.

The analysis of the linear correlation shows the existence of a positive correlation between the factors of coping and the quality of life, existing a strong correlation with the Avoidance factor $(r=0.916 ; p=0.0001)$. The Control factor correlates with the domains of quality of life Physical health $(r=0.174 ; p=0.017)$, Psychological $(r=0.160 ; p=0.027)$ and the Environment $(r=0.143 ; p=0.049)$. The Avoidance factor also had a strong correlation with the Physical domain ( $r=0.838 ; p=0.0001)$, followed by Psychological $(r=0.752$; $p=0.0001)$, the Environment $(r=0.726 ; p=0,0001)$ and Social Relationships ( $r=0.622 ; p=0.001)$. The Symptoms Management factor has a correlation with the Psychological domain $(r=0.269 ; p=000.1)$, the Environment $(r=0.256 ; p=0.0001)$, the Physical health $(r=0.234$; $p=0.001)$ and the Social Relationships $(r=0.118 ; p=0.105)$ (Table 2$)$.

Table 2 - Analysis of linear correlation between WHOQOL-bref and Occupational Coping Scale

\begin{tabular}{|c|c|c|c|c|c|c|}
\hline & \multicolumn{6}{|c|}{ Occupational Coping Scale } \\
\hline & \multicolumn{2}{|c|}{$\begin{array}{l}\text { Control } \\
\text { Factor }\end{array}$} & \multicolumn{2}{|c|}{$\begin{array}{l}\text { Avoidance } \\
\text { Factor }\end{array}$} & \multicolumn{2}{|c|}{$\begin{array}{c}\text { Symptoms } \\
\text { Management } \\
\text { Factor }\end{array}$} \\
\hline & $\mathbf{r}^{\dagger}$ & $p$ value & $\mathbf{r}^{\dagger}$ & $p$ value & $\mathbf{r}^{\dagger}$ & $p$ value \\
\hline $\mathrm{QOL}^{*}$ & 0.181 & 0.013 & 0.916 & 0.0001 & 0.284 & 0.0001 \\
\hline Physical health Domain & 0.174 & 0.017 & 0.838 & 0.0001 & 0.234 & 0.001 \\
\hline Psychological Domain & 0.160 & 0.027 & 0.752 & 0.0001 & 0.269 & 0.0001 \\
\hline Social Relationships Domain & 0.084 & 0.249 & 0.622 & 0.0001 & 0.118 & 0.105 \\
\hline Environment Domain & 0.143 & 0.049 & 0.726 & 0.0001 & 0.256 & 0.0001 \\
\hline
\end{tabular}

Note: * World Health Organization Quality of Life Bref, ${ }^{\dagger}$ Pearson's correlation coefficient.

When seeking to identify the difference in quality of life for socioeconomic data, we made a comparison of the means of quality of life in relation to gender, age group, length of work experience in hospital care, academic titles, family income, shift, weekly workload and unit of action between public tenured and outsourced workers (Table 3 ).

Tenured female nurses had a better quality of life (67.41) than same-sex outsourced workers (62.10) $(p=0.006)$. Tenured workers (69.04) in the 40 to 66 age group also had a better quality of 
life than outsourced workers (61.25) $(p=0.005)$. Regarding the degree, tenured nurses (67.04) who were specialists, had a better quality of life than outsourced workers (61.93) ( $p=0.028)$ (Table 3).

Tenured nurses (68.34) with a family income of 2.5 to 6.8 minimum wages had a better quality of life than outsourced nurses (60.32) $(p=0.021)$. Tenured nurses who worked only in the morning or the afternoon (70.10) had a better quality of life than outsourced workers (61.20) $(p=0.043)$, as well as those who worked in the morning and afternoon (69.51), compared to outsourced workers (63.57) $(p=0.038)$. Tenured nurses (67.22) who worked in a critical care unit, had a better quality of life than outsourced workers (61.06) $(p=0.032)$ (Table 3).

Table 3 - Distribution of the means of the quality of life for tenured nurses and outsourced nurses according to socioeconomic data

\begin{tabular}{|c|c|c|c|}
\hline & $\begin{array}{c}\text { QOL* }^{*} \\
\text { tenured } \\
\text { Mean } \pm \text { SD }^{+}\end{array}$ & $\begin{array}{c}\text { QOL* } \\
\text { outsourced } \\
\text { Mean } \pm \text { SD }^{\dagger}\end{array}$ & $\stackrel{p}{\text { value }^{\S}}$ \\
\hline \multicolumn{4}{|l|}{ Gender } \\
\hline Female & $67.41 \pm 11.21$ & $62.10 \pm 11.40$ & 0.006 \\
\hline Male & $63.89 \pm 8.36$ & $62.83 \pm 12.35$ & 0.958 \\
\hline \multicolumn{4}{|l|}{ Age group } \\
\hline $23-39$ & $59.72 \pm 12.16$ & $62.32 \pm 11.89$ & 0.528 \\
\hline $40-66$ & $69.04 \pm 10.03$ & $61.25 \pm 8.57$ & 0.005 \\
\hline \multicolumn{4}{|l|}{$\begin{array}{l}\text { Time (years) of work experience } \\
\text { in hospital care }\end{array}$} \\
\hline $1-10$ & $63.19 \pm 12.12$ & $61.95 \pm 11.61$ & 0.798 \\
\hline $11-38$ & $67.79 \pm 10.86$ & $64.67 \pm 9.83$ & 0.379 \\
\hline \multicolumn{4}{|l|}{ Academic Titles } \\
\hline Undergraduate & $67.45 \pm 8.22$ & $61.48 \pm 11.84$ & 0.329 \\
\hline Specialization & $67.04 \pm 10.64$ & $61.93 \pm 11.32$ & 0.028 \\
\hline Master's Degree & $67.58 \pm 14.63$ & $66.84 \pm 10.70$ & 0.898 \\
\hline \multicolumn{4}{|l|}{ Family Income ${ }^{\ddagger}$} \\
\hline $2.5-6.8$ & $68.34 \pm 9.15$ & $60.32 \pm 11.42$ & 0.021 \\
\hline $6.9-12.3$ & $63.69 \pm 14.22$ & $62.59 \pm 12.99$ & 0.781 \\
\hline $12.4-38.5$ & $67.52 \pm 8.90$ & $63.72 \pm 9.49$ & 0.165 \\
\hline \multicolumn{4}{|l|}{ Shift } \\
\hline Morning or afternoon & $70.10 \pm 9.77$ & $61.20 \pm 12.70$ & 0.043 \\
\hline Morning and Afternoon & $69.51 \pm 6.03$ & $63.57 \pm 10.21$ & 0.038 \\
\hline Night & $62.88 \pm 12.09$ & $62.93 \pm 11.04$ & 0.991 \\
\hline Morning or Afternoon or Night & $65.28 \pm 16.19$ & $59.31 \pm 12.37$ & 0.311 \\
\hline \multicolumn{4}{|l|}{ Workload } \\
\hline 20-39 & $68.42 \pm 8.71$ & $63.05 \pm 11.80$ & 0.089 \\
\hline $40-59$ & $68.16 \pm 12.00$ & $64.41 \pm 10.97$ & 0.230 \\
\hline $60-96$ & $63.23 \pm 13.34$ & $57.95 \pm 11.06$ & 0.196 \\
\hline \multicolumn{4}{|l|}{ Unit } \\
\hline Critical & $67.22 \pm 8.86$ & $61.06 \pm 10.92$ & 0.032 \\
\hline Non-critical & $67.15 \pm 12.28$ & $63.59 \pm 12.07$ & 0.199 \\
\hline
\end{tabular}

Note: ${ }^{*}$ Quality of life, ${ }^{+}$Standard deviation, ${ }^{*}$ Family income is presented in minimum wages, corresponding to $R \$ 724.00$ in 2014, Brazil, ${ }^{5}$ Student $t$-test.

When seeking to identify the relation between socioeconomic data and the Avoidance factor, the only one with statistically significance difference, we compared the means of this factor in relation to gender, age group, length of work experience in hospital care, academic titles, family income, shift, weekly workload and unit of tenured and outsourced nurses (Table 4).

Regarding the Avoidance factor, the female gender (66.80) adopted this set of strategies more than the male gender (58.94) ( $p$ $<0001)$. Tenured nurses (68.59) in the 40 to 66 age group adopted more avoidance strategies than outsourced workers (61.67) $(p=$ 0.031 ), as well as specialist tenured (65.66), compared to outsourced workers who had the same title (58.30) $(p=0.005)$. Tenured workers
(68.29), with a family income of 2.5 to 6.8 minimum wages, also adopted this strategy more than outsourced workers (57.36) $(p=$ 0.006). Finally, applicants who worked in the morning or afternoon (68.61) and morning and afternoon (69.26) adopted the Avoidance factor more than outsourced workers (57.28) $(p=0.020),(61.24)(p$ $=0.007$ ), respectively. We observed the presence of these socioeconomic variables in the influence of the highest quality of life and the use of the Avoidance factor between the tenured nurses.

Table 4 - Distribution of the means of the Avoidance factor of tenured and outsourced nurses according to socioeconomic data

\begin{tabular}{|c|c|c|c|}
\hline & $\begin{array}{l}\text { Avoidance } \\
\text { factor for } \\
\text { tenured nurses } \\
\text { Mean } \pm \text { SD* }\end{array}$ & $\begin{array}{c}\text { Avoidance factor } \\
\text { for outsourced } \\
\text { nurses } \\
\text { Mean } \pm \text { SD* }\end{array}$ & $\underset{\text { value }^{\ddagger}}{\boldsymbol{p}}$ \\
\hline \multicolumn{4}{|l|}{ Gender } \\
\hline Female & $66.80 \pm 13.57$ & $58.94 \pm 12.81$ & $<0.0001$ \\
\hline Male & $53.70 \pm 6.99$ & $57.12 \pm 12.13$ & 0.487 \\
\hline \multicolumn{4}{|l|}{ Age group } \\
\hline 23-39 & $55.25 \pm 15.30$ & $58.27 \pm 13.08$ & 0.509 \\
\hline $40-66$ & $68.59 \pm 11.91$ & $61.67 \pm 9.90$ & 0.031 \\
\hline \multicolumn{4}{|l|}{$\begin{array}{l}\text { Length (years) of work } \\
\text { experience in hospital care }\end{array}$} \\
\hline $1-10$ & $57.87 \pm 13.31$ & $58.33 \pm 12.83$ & 0.931 \\
\hline $11-38$ & $67.16 \pm 13.36$ & $63.19 \pm 10.80$ & 0.353 \\
\hline \multicolumn{4}{|l|}{ Academic Titles } \\
\hline Undergraduate & $66.67 \pm 9.35$ & $58.06 \pm 12.82$ & 0.196 \\
\hline Specialization & $65.66 \pm 12.78$ & $58.30 \pm 12.43$ & 0.005 \\
\hline Master's Degree & $66.67 \pm 19.36$ & $64.58 \pm 13.82$ & 0.781 \\
\hline \multicolumn{4}{|l|}{ Family Incomeł } \\
\hline $2.5-6.8$ & $68.29 \pm 11.14$ & $57.36 \pm 11.80$ & 0.006 \\
\hline $6.9-12.3$ & $60.71 \pm 17.53$ & $59.11 \pm 14.04$ & 0.717 \\
\hline $12.4-38.5$ & $66.83 \pm 10.41$ & $60.07 \pm 12.01$ & 0.048 \\
\hline \multicolumn{4}{|l|}{ Shift } \\
\hline Morning or afternoon & $68.61 \pm 11.19$ & $57.28 \pm 13.94$ & 0.020 \\
\hline Morning and Afternoon & $69.26 \pm 7.00$ & $61.24 \pm 10.14$ & 0.007 \\
\hline Night & $61.11 \pm 13.26$ & $59.13 \pm 13.30$ & 0.661 \\
\hline $\begin{array}{l}\text { Morning or } \\
\text { Afternoon or Night }\end{array}$ & $63.27 \pm 22.34$ & $55.21 \pm 13.37$ & 0.268 \\
\hline \multicolumn{4}{|l|}{ Workload } \\
\hline 20-39 & $67.40 \pm 9.53$ & $60.78 \pm 14.09$ & 0.074 \\
\hline $40-59$ & $67.36 \pm 16.12$ & $60.78 \pm 11.84$ & 0.067 \\
\hline $60-96$ & $60.83 \pm 15.85$ & $53.87 \pm 11.83$ & 0.123 \\
\hline \multicolumn{4}{|l|}{ Unit } \\
\hline Critical & $63.89 \pm 10.76$ & $57.65 \pm 12.27$ & 0.440 \\
\hline Non-critical & $67.16 \pm 15.10$ & $60.11 \pm 13.22$ & 0.280 \\
\hline
\end{tabular}
$R \$ 724.00$ in 2014, Brazil, §Student t-test.

\section{DISCUSSION}

The main factors that influence nurses' quality of life are related to personal characteristics (age, domestic condition), health behaviors (sleep, diet, exercise) and work characteristics (length of work experience, night shift work, schooling, inadequate hours of work, lack of facilities to rest, lack of professional development opportunities, precarious working environment in terms of security and insufficient inputs and salary) ${ }^{(11)}$. These factors are of great importance to society, as they can affect the quality of health care provision ${ }^{(12)}$.

All the factors mentioned above are a reality in the outsourced professionals' life since they are subject to shifts and sectors 
rejected by the permanent team, hindering leisure and social life. Besides, the professionals' degree does not interfere in any in the value paid to the outsourced worker for the hour worked, contributing to professional stagnation and devaluation. The research findings confirm the empirical observations regarding the lower quality of life of the outsourced workers.

The present study revealed nurses' quality of life values similar to those found worldwide. In Croatia, the Physical domain had a mean of 71.4, while for tenured nurses (70.08) and outsourced nurses (64.58) in the present study, which obtained lower scores. The Psychological domain had a mean of 66.7, which is lower than the one found for tenured nurses (68.52) and higher than the one found for the outsourced nurses (66.12) of this research. The Environment domain had a mean of 59.4, which was also lower than the one found for tenured nurses (63.36) and higher than the one for the outsourced (55.40). The Social Relationships domain obtained a much better result than in Brazil (experience of 75.0), being higher for tenured (70.56) and outsourced (66.49) nurses ${ }^{(13)}$. For Brazilian assistants, technicians, and nurses, the following values were found: Physical health domain (48.63), Psychological domain (57.31), Social Relationships domain (49.65), and Environment domain (46.4) ${ }^{(14)}$. For rescue professionals, the mean scores related to the WHOQOL-bref domains were: 74.6 , in Physical; 74.6, in Psychological; 76.5, in Social relationships; and 58.7, in the Environment ${ }^{(15)}$.

A proportion of nurses reported a good perception of the quality of life correlated to high work productivity, reinforcing the need for investment in nurses' quality of life at work in order to increase their productivity ${ }^{(16)}$. In the public sphere, the agencies manifest this reality by putting pressure on reducing expenses and increasing productivity, reducing the number of tenured workers in the staff, which are gradually being replaced by people with precarious employment relationships; and lack of concern for the quality of life of employees ${ }^{(17)}$.

The precariousness of employment relationships, in turn, contributes to occupational stress and dissatisfaction, which can compromise the work process, in addition to bringing losses to the institution. It is perceived, by the permanent professionals, as the cause of the high employee turnover, requiring constant training of a workforce, that is sometimes dubious ${ }^{(18)}$.

It is noteworthy that it was not possible to compare nurses' quality of life results concerning employment relationships, as we found no studies that consider this variable. However, the data found suggest urgent investigations, since starting from the relationship already established between the subjective issues of the worker with the quality of care and taking into account the growing reality of precarious employment relationships, the worse quality of life of the outsourced nurses cannot be neglected.

The investigation data reveal, therefore, the precariousness of labor relationships established with nurses in Ceará, as $76.3 \%$ are outsourced workers, without a permanent employment relationship, and only $23.7 \%$ are tenured workers. This precariousness of work in the health sector has been the result of government policies and highlights the need for public examinations to guarantee labor rights ${ }^{(19)}$. Worldwide, the reality is similar; $47.5 \%$ of Australian nurses work in precarious jobs: part-time or casual or seasonal jobs through employment contract and temporary contingent work ${ }^{(20)}$. Accordingly, there is evidence of an association between some dimensions of precarious work, such as insecurity, time control, precarious career paths, various jobs, temporary employment, and hourly pay with occupational accidents ${ }^{(21)}$.

Socioeconomic data (female gender, age ranged from 40 to 66 , specialist degree, family income of 2.5 to 6.8 minimum wages and morning or afternoon work shift as well as morning and afternoon) showed a higher quality of life and predominance of the Avoidance factor for tenured when compared to outsourced workers. From this, it is possible to suggest the considered pattern as stable in the profession, with an admittedly female predominance; stable employment relationship; older age group, suggesting acquisition of durable goods and family structure; day shifts, like most of the population, providing more excellent family and social life.

However, the factors mentioned above, which possibly provide a better quality of life, reflect the avoidance of problems in the work environment. We believe that the stability of the legal regime of public servants can be a factor that allows these actions without risk of dismissal, or even the longer length of work of these professionals, who have already used all the proactive coping without seeing better results, can lead to evasion as a consequence. However, we mentioned that there is a need for more in-depth research for these statements.

The findings revealed that the occupational coping, predominant in the Control factor, was the most adopted by nurses, without pointing out a statistically significant difference for tenured and outsourced workers. However, there were high values for the Avoidance factor. Resistance and problem-solving skills are protective factors against stress among nurses and should be worked on during academic training. The Problem Resolution strategy aims at changing a situation through a critical and detailed assessment of the problem in order to obtain satisfactory results ${ }^{(22)}$. A study with 96 Portuguese nurses found a significant negative correlation between general health and avoidance coping strategy. That is, the lower the health, the more the avoidance occurred ${ }^{(23)}$. However, strategies focused on removing the individual from stressors can be protective in specific situations of crisis or inability to resolve problems.

A survey with 32 Australian nurses identified, among the main strategies used to cope with stress, the use of social media and spaces for hospital employees; the practice of exercises, family activities and housework; and sleep - strategies that also belong to the Avoidance and Symptom Management factor ${ }^{(24)}$.

In the present study, we found that there is a strong relationship between the adoption of strategies aimed at Control and the Social Relationships factor; and the Avoidance factor has less connection with Social Relationships. The coping centered on the problem was the most adopted by nurses, presenting better results in Social Relationships. The fact that explains this evidence is that in social relationships, nurses find more significant support for problem-solving. The worrying and susceptible fact of interventions is that the Environment domain has the lowest correlation with the Control factor and high correlation with the Avoidance factor, requiring interventions. Likewise, the Physical and Psychological domains also need interventions to improve coping ${ }^{(24)}$. 
It becomes evident the urgency in professional appreciation, through public examinations and improvement in career plans, since the fight against the precariousness of nursing work must be a struggle to improve the professional's quality of life and, consequently, the assistance provided by these workers.

\section{Study Limitations}

The present research was conducted in only one public hospital, which may compromise the generalization of the findings for scenarios and contexts different from the place and public investigated. In addition, due to the method chosen, we considered necessary to carry out more in-depth investigations between cause and effect, as well as on the influence of the worst quality of life in care practice.

\section{Contributions to nursing, health, or public policy fields}

This study evidenced the damage caused to the worker's quality of life, in the face of the precarious employment relationships that are increasingly present in hospitals. Besides, the findings of the present study contribute to bridging the knowledge gap about aspects related to the quality of life and occupational coping of nursing professionals in different types of employment relationships. We expect the results to subsidize interventions that contribute to improvements in the field of occupational health and guide the decision-making of managers concerning the choice of employment modality of health professionals.

\section{CONCLUSION}

The data revealed that being an outsourced nurse was associated with a worse quality of life. However, being a tenured nurse revealed a greater use of avoidance strategies in solving work problems. There was a strong relationship between the adoption of strategies aimed at Control and the Social Relationships factor, and the Avoidance factor has less connection with Social Relationships. Female tenured nurses, between $40-66$ years old, specialists, having a family income of 2.5 to 6.8 minimum wages, and working in the morning or afternoon as well as morning and afternoon showed a difference in the quality of life and the Avoidance factor. These variables interfere in the quality of life and the occupational coping of these health workers. Therefore, there is a need to promote occupational health for both groups, tenured and outsourced, guiding the coping strategies that each group needs.

\section{REFERENCES}

1. Gómez-Urquiza JL, Aneas-López AB, Fuente-Solana El, Albendín-García L, Díaz-Rodríguez L, Fuente GA. Prevalence, risk factors, and levels of burnout among oncology nurses: a systematic review. Oncol Nurs Forum[Internet]. 2016 [cited 2017 Aug 5];43(3):104-20. Available from: http://www.medscape.com/viewarticle/862945

2. Adriaenssens J, Gucht V, Maes S. Causes and consequences of occupational stress in emergency nurses, a longitudinal study. J Nurs Manag[Internet]. 2015 [cited 2017 Aug 5];23(3):346-58. Available from: http://www.ncbi.nlm.nih.gov/pubmed/24330154

3. Büssing A, Falkenberg Z, Schoppe C, Recchia DR, Poier D. Work stress associated cool down reactions among nurses and hospital physicians and their relation to burnout symptoms. BMC Health Serv Res. [Internet]. 2017 [cited 2018 Mar 15];17(1):551. Available from: https://www. ncbi.nlm.nih.gov/pmc/articles/PMC5553651

4. Skevingtona SM, Dehner S, Gillison FB, McGrath EJ, Lovell CR. How appropriate is the WHOQOL-BREF for assessing the quality of life of adolescents? Psychol Health[Internet] 2014[cited 2017 Jun 5];29(3):297-317. Available from: http://www.ncbi.nlm.nih.gov/ pubmed/24192254

5. Wright RR, Mohr CD, Sinclair RR, Yang LQ. Sometimes less is more: directed coping with interpersonal stressors at work. J Organ Behav[Internet]. 2015 [cited 2018 Jan 04];36(6):786-805. Available from: http://onlinelibrary.wiley.com/doi/10.1002/job.2002/abstract

6. Paek MS, Ip E, Levine B, Avis N. Longitudinal Reciprocal Relationships Between Quality of Life and Coping Strategies Among Women with Breast Cancer. Ann Behav Med[Internet]. 2016[cited 2017 Nov 20]:1-9. Available from: http://link.springer.com/article/10.1007/s12160-016-9803-y

7. Secretaria Estadual de Saúde do Ceará. Hospital Geral de Fortaleza: uma história, uma trajetória. Ceará: Secretaria Estadual de Saúde; 2015. Available from: http://www.hgf.ce.gov.br/index.php/apresentacao/apresentacao

8. The WHOQOL Group. The World Health Organization quality of life assessment: position paper from the World Health Organization. Soc Sci Med[Internet]. 1995 [cited 2016 Dec 2];41(10):1403-9. Available from: http://www.ncbi.nlm.nih.gov/pubmed/8560308

9. Cheung YB, Yeo KK, Chong KJ, Khoo EY, Wee HL. Reliability and Validity of the English-, Chinese- and Malay-Language Versions of the World Health Organization Quality of Life (WHOQOL-BREF) Questionnaire in Singapore. Ann Acad Med Singapore [Internet]. 2017 [cited 2018 Feb 26];(12):461-9. Available from: https://www.ncbi.nlm.nih.gov/pubmed/29355283

10. Umann J, Guido LA, Silva RM. Stress, coping and presenteeism in nurses assisting critical and potentially critical patients. Rev Esc Enferm USP [Internet]. 2014 [cited 2018 Jan 24];48(5):891-8. Available from: http://www.scielo.br/pdf/reeusp/v48n5/0080-6234-reeusp-48-05-891.pdf

11. Oyama Y, Fukahori H. A literature review of factors related to hospital nurses' health-related quality of life. J Nurs Manag[Internet]. 2015 [cited 2018 Jan 20];23(5):661-73. Available from: https://www.ncbi.nlm.nih.gov/pubmed/25807874. doi: 10.1111/jonm.12194

12. Hall LH, Johnson J, Watt I, Tsipa A, O'Connor DB. Healthcare staff wellbeing, burnout, and patient safety: a systematic review. PLoS One[Internet]. 2016 [cited 2018 Feb 03];11:e0159015. Available form: http://journals.plos.org/plosone/article/file?id=10.1371/journal. pone.0159015\&type $=$ printable 
13. Sorić M, Golubić R, Milosević M, Juras K, Mustajbegović, J. Shift work, quality of life and work ability among Croatian hospital nurses. Coll Antropol[Internet]. 2013 [cited 2017 Jul 2];37(2):379-84. Available from: http://www.ncbi.nlm.nih.gov/pubmed/23940978

14. Santos TM, Kozasa EH, Carmagnani IS, Tanaka LH, Lacerda SS, Nogueira-Martins LA. Positive effects of a stress reduction program based on mindfulness meditation in Brazilian nursing professionals: qualitative and quantitative evaluation. Explore (NY). [Internet]. 2016 [cited 2017 Jul 2];12(2):90-9. http://www.ncbi.nlm.nih.gov/pubmed/26778081

15. Marconato RS, Monteiro MI. Pain, health perception and sleep: impact on the quality of life of firefighters/rescue professionals. Rev Latino-Am Enfermagem. [Internet]. 2015 [cited 2018 Mar 2]; 23(6):991-9. Available from: https://www.scielo.br/pdf/rlae/v23n6/0104-1169rlae-23-06-00991.pdf

16. Koushki, MS, Mohammad A. Quality of working life and its relation with productivity of nurses' performance in Shahid Beheshti University of Medical Sciences Hospitals. Sjsph[Internet]. 2013 [cited 2017 Jun 20];10(4):81-90. Available from: http://sjsph.tums.ac.ir/browse. php?a_code=A-10-25-6\&sid=1\&slc_lang=en

17. Gonçalves FGA, Souza NVDO, Zeitoune RCG, Adame GFPL, Nascimento SMP. Impacts of neoliberalism on hospital nursing work. Texto Context Enferm[Internet]. 2015 [cited 2018 Feb 13];24(3):646-53. Available from: http://www.scielo.br/pdf/tce/v24n3/0104-0707tce-24-03-00646.pdf

18. Souza NVDO, Gonçalves FGA, Pires AS, David HMSL. Neoliberalist influences on nursing hospital work process and organization. Rev Bras Enferm[Internet]. 2017 [cited 2018 Mar 12]; 70(5):912-9. Available from: http://www.scielo.br/pdf/reben/v70n5/0034-7167reben-70-05-0912.pdf

19. Vieira MLC, Oliveira EB, Souza NVDO, Lisboa MTL, Xavier T, Rossone FO. Precarização do trabalho em hospital de ensino e presenteísmo na enfermagem. Rev Enferm UERJ[Internet]. 2016 [cited 2017 Dec 12];24(4):e23580. Available from: http://www.e-publicacoes.uerj.br/index. php/enfermagemuerj/article/view/23580/19433

20. Batch M, Windsor C. Nursing casualization and communication: a critical ethnography. J Adv Nurs. [Internet]. 2015 [cited 2018 Apr 2];71(4):870-80. Available from: http://www.ncbi.nlm.nih.gov/pubmed/25376326

21. Koranyi I, Jonsson J, Rönnblad T, Stockfelt L, Bodin T. Precarious employment and occupational accidents and injuries - a systematic review. Scand J Work Environ Health [Internet]. 2018 [cited 2018 Jun 20];44(4):341-50. Available from: http://www.sjweh.fi/show_abstract. php?abstract_id=3720. doi:10.5271/sjweh.3720

22. Abdollahi A, Talib MA, Yaacob SN, Ismail Z. Problem-solving skills and hardiness as protective factors against stress in Iranian nurses. Issues Ment Health Nurs [Internet]. 2014 [cited 2017 Jan 06];35(2):100-7. Available from: https://www.tandfonline.com/doi/abs/10.3109/01612840. 2013.843621?journalCode=imhn20

23. Gomes SFS, Santos MMMCC, Carolino ETMA. Psycho-social risks at work: stress and coping strategies in oncology nurses. Rev LatinoAm Enfermagem[Internet]. 2013 [cited 2017 Feb 12];21(6):1282-9. Available from: https://www.scielo.br/pdf/rlae/v21n6/0104-1169rlae-0213-2365.pdf

24. Happell B, Reid-Searl K, Dwyer T, Caperchione CM, Gaskin CJ, Burke KJ. How nurses cope with occupational stress outside their workplaces. Collegian[Internet]. 2013 [cited 2017 Nov 5];20(3):195-9. Available from: http://www.ncbi.nlm.nih.gov/pubmed/24151698 